\title{
PENGARUH MAKROEKONOMI TERHADAP NON PERFORMING LOAN (NPL) PERBANKAN
}

\author{
(The Influence of Macroeconomic Factor to Non Performing Loan (NPL) Banks)
}

\author{
Ari Mulianta Ginting \\ Puslit, Bidang Ekonomi dan Kebijakan Publik, BK DPR RI \\ Gedung Nusantara 1, Lantai 2, Setjen DPR RI \\ JI. Jenderal Gatot Subroto, Jakarta, 10270 \\ Email: ari.ginting@dpr.go.id \\ Naskah diterima: 16 Januari 2016 \\ Naskah direvisi: 19 Januari 2016 \\ Naskah diterbitkan: 30 Desember 2016
}

\begin{abstract}
One of the industries that have been influenced by the macroeconomic condition is the banking industry. It happened because the banking industry is very sensitive to the economic condition of a country. If the economic condition of the country is developing, then the banking industry also developing. But if the economic condition is in crisis then this could result in an impact on the banking industry. Therefore the national macroeconomic condition should be noticed for lending credits. This study aims is to see the development of credit growth and the NPL in Indonesia and to determine the influence of macroeconomic variables on the bank's NPL credit. This study used qualitative and quantitative methods. Quantitative method used dynamic panel data from 2006 through 2014. The result found that the credit growth in the period was increasing. The increasing credit was followed by the increase of the NPL. This study also found that macroeconomic condition, particularly the GDP had a negative influence on the NPL, meaning that the increasing of economic growth would reduce the NPL. This research also found that interest rate loan and inflation have positive and significant effect to the NPL. Therefore, government should work closer with Central Bank to make a better macroeconomic condition in order to decrease the NPL in Indonesia.

Keywords: macroeconomic, banking industry, non performing loan
\end{abstract}

\begin{abstract}
Abstrak
Salah satu industri yang memiliki keterkaitan dengan makroekonomi adalah industri perbankan, hal ini dikarenakan industri perbankan sangat peka dengan kondisi perekonomian suatu negara. Jika suatu perekonomian suatu negara sedang berkembang, maka industri perbankan juga dapat berkembang. Namun kondisi sebaliknya ketika perekonomian sedang mengalami krisis, maka hal ini dapat mengakibatkan dampak terhadap industri perbankan. Oleh karena itu kondisi makroekonomi Indonesia menjadi suatu hal yang harus diperhatikan bagi penyaluran kredit perbankan. Studi ini bertujuan untuk mengetahui perkembangan kredit dan kredit macet (NPL) perbankan di Indonesia dan mengetahui pengaruh variabel makroekonomi terhadap NPL perbankan di Indonesia. Studi ini menggunakan metode kualitatif dan kuantitatif. Pendekatan kuantitatif menggunakan metode dynamic panel data yang menggunakan data dari tahun 2006-2014. Hasil studi ini menunjukkan bahwa perkembangan kredit dalam periode tersebut mengalami tren meningkat, peningkatan kredit yang disalurkan oleh perbankan diikuti oleh peningkatan NPL perbankan. Studi ini juga menemukan bahwa ternyata kondisi makroekonomi, terutama GDP, memiliki pengaruh yang negatif terhadap NPL. Artinya jika semakin membaiknya perekonomian yang ditandai dengan semakin meningkatnya pertumbuhan ekonomi akan semakin mengurangi NPL dan memiliki pengaruh yang positif dengan variabel tingkat suku bunga pinjaman serta inflasi. Berdasarkan temuan tersebut maka diperlukan sinergitas antara pemerintah sebagai otoritas fiskal dengan Bank Indonesia untuk menciptakan kondisi makroekonomi yang baik yang dapat mengurangi kredit macet perbankan di Indonesia.

Kata kunci: makroekonomi, industri perbankan, kredit macet
\end{abstract}

\section{PENDAHULUAN}

\section{A. Latar Belakang}

Proses rebalancing ekonomi dunia mewarnai dinamika perkembangan negara maju dan emerging markets (EM) pada tahun 2014. Di tengah dinamika perekonomian global yang kurang menguntungkan, kinerja perekonomian Indonesia berhasil dilalui dengan kinerja stabilitas makroekonomi yang semakin kokoh dan proses penyesuaian ekonomi ke arah yang lebih sehat. Keberhasilan ini tercermin pada laju inflasi yang terkendali, defisit transaksi berjalan yang menurun, surplus transaksi modal dan finansial yang tinggi, volatilitas nilai tukar yang bergerak dalam tren menurun, dan defisit fiskal yang terjaga (Bank Indonesia, 2015a).

Dari paparan tersebut maka menunjukkan bahwa kondisi terakhir tahun 2014 makroekonomi Indonesia berada dalam keadaan yang cukup kondusif dan aman. Kondisi makroekonomi yang kondusif dan aman diperlukan bagi perkembangan dunia usaha. Karena menurut Rose \& Hudgins (2005) akibat globalisasi ekonomi yang telah merubah perilaku dunia usaha, dan telah memengaruhi perkembangan perekonomian Indonesia khususnya sektor perbankan. Bank sebagai salah satu institusi keuangan penting dalam perekonomian karena 


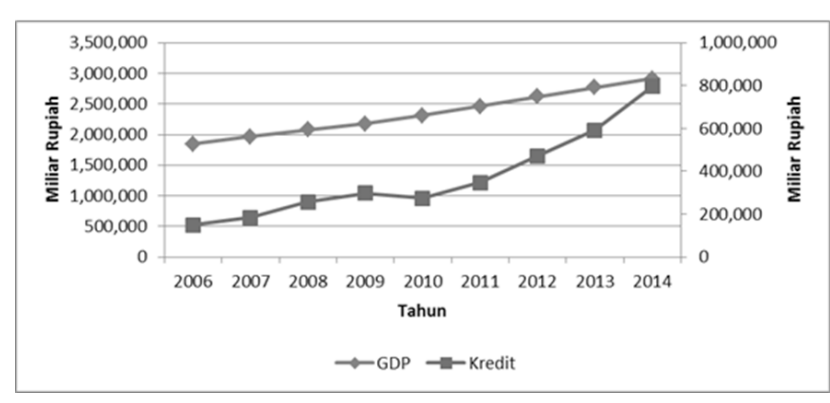

Sumber: BPS, 2015 dan Bank Indonesia, 2015b (diolah).

Gambar 1. Perkembangan Total Kredit Bank Umum dan Total GDP atas Harga Konstan

kegiatan bank di antaranya adalah penghimpun dan alokasi dana dalam kredit, pelayanan jasa keuangan masyarakat, dengan tujuan meningkatkan taraf hidup rakyat banyak di Indonesia.

Lebih lanjut menurut Sarah, et al. (2011) industri perbankan adalah salah satu industri yang paling terpengaruh dengan keadaan luar perusahaan misalnya keadaan makroekonomi yang dialami Indonesia. Berbagai peristiwa ekonomi makro telah mewarnai aktivitas perbankan. Semakin meningkatnya aktivitas perbankan telah meningkatkan mobilitas dana pada sektor perbankan. Berbagai macam aktivitas yang dilakukan oleh bank ternyata juga dilakukan oleh lembaga keuangan selain bank. Walaupun semakin ketat persaingan antarlembaga keuangan tetapi industri perbankan diharapkan memberikan kontribusi yang besar dalam perkembangan nasional hingga saat ini.

Salah satu kegiatan utama dari bank adalah melakukan intermediasi keuangan. Bank mengimpun dana dari masyarakat dan kemudian menyalurkannya kembali kepada masyarakat melalui kredit. Bisnis kredit merupakan bisnis utama dari perbankan dan menjadi salah satu bisnis dengan perkembangan yang cukup pesat di Indonesia seiring dengan meningkatnya aktivitas perekonomian. Hal ini bisa terlihat dari Gambar 1.

Tahun 2006 jumlah kredit yang disalurkan kepada perekonomian berjumlah Rp796.767 miliar meningkat hampir 365,37 persen pada tahun 2014 menjadi Rp3.707.916 miliar. Sedangkan pada tahun 2006 total Gross Domestic Product (GDP) Indonesia berdasarkan harga konstan tahun 2000 adalah sebesar Rp1.847.127 miliar mengalami pertumbuhan yang positif sebesar 149 persen pada tahun 2013 menjadi Rp2.770.345 miliar. Berdasarkan Gambar 1 terlihat pergerakan tren yang positif antara GDP dengan kredit yang disalurkan. Atau dapat dikatakan bahwa peningkatan jumlah kredit yang disalurkan ini seiring dan sejalan dengan tren perkembangan perekonomian yang mengalami pertumbuhan GDP. Seiring dengan semakin meningkatnya aktivitas perkonomian maka semakin banyak jumlah kredit yang disalurkan oleh perbankan untuk membantu pembiayaan proses pembangunan tersebut.

Namun di sisi lain, peningkatan jumlah kredit seperti yang diuraikan di atas masih cukup rentan risiko. Hal tersebut tercermin dari peningkatan jumlah kredit bermasalah (non performing loan, NPL) perbankan, NPL kredit perbankan cenderung mengalami tren peningkatan pada Triwulan IV tahun 2014. Peningkatan ini khususnya pada kredit modal kerja dan kredit investasi yang disalurkan oleh perbankan (Bank Indonesia, 2015b). Banyak faktor yang menyebabkan meningkatnya tingkat nilai $N P L$, salah satunya adalah indikator makroekonomi seperti tingkat suku bunga. Bank Indonesia sebagai lembaga yang berwenang mengendalikan tingkat suku bunga juga berdampak pada kredit yang disalurkan perbankan. Tingginya tingkat suku bunga menyebabkan suku bunga kredit perbankan ikut naik sehingga dapat mengurangi kemampuan bayar debitur dalam membayar pinjamannya. Hal ini tentu akan menyebabkan meningkatnya nilai dan rasio NPL. Meningkatnya nilai NPL selain dipengaruhi indikator makroekonomi juga dapat dipengaruhi oleh faktor internal perbankan yang menyalurkan kredit serta faktor internal pihak yang menerima kredit (Alam, 2008).

Terkait dengan hal tersebut, banyak penelitian yang telah mencoba menganalisis pengaruh makroekonomi terhadap NPL. Salah satu kontroversi utama di kalangan para ahli ekonomi pembangunan sejak tahun 1960-an adalah kausalitas antara sektor finansial dengan sektor riil dengan NPL. Pengaruh kondisi makroekonomi terhadap NPL terhadap risiko kredit, khususnya NPL, dilakukan Quangliariello (2007) yang menemukan bahwa kondisi performa makroekonomi yang menurun dapat meningkatkan risiko terjadinya NPL. Bukti empiris untuk Indonesia dengan data kuartalan selama tahun 19891994 menunjukkan adanya hubungan kausalitas satu arah antara kinerja ekonomi dengan kredit perbankan (Kuncoro, 2011). Penelitian yang dilakukan oleh Bofondi \& Ropele (2011) terhadap perbankan Itali menemukan hasil bahwa perubahan kondisi makroekonomi umumnya memengaruhi kualitas kredit. Jolevska \& Andovski (2014) mengemukakan bahwa kondisi perekonomian menjadi faktor yang menentukan tingkat NPL di suatu negara.

Lebih lanjut mengenai NPL, berdasarkan penelitian yang dilakukan dengan menggunakan data dari 16 bank dari negara Tunisia periode waktu tahun 20032012 disimpulkan bahwa NPL yang terjadi di perbankan banyak dipengaruhi oleh variabel makroekonomi, variabel makroekonomi tersebut terdiri dari GDP, inflasi, dan tingkat suku bunga (Abid, et al., 2014). Hal senada dikemukakan dalam penelitian yang dilakukan menggunakan data dari 75 negara di Eropa dan 
ditemukan bahwa variabel makroekonomi seperti GDP riil, harga saham, nilai tukar, dan tingkat suku bunga memengaruhi terjadi NPL (Beck, et al., 2013).

Terkait dengan paparan di atas, maka dapat disimpulkan banyak penelitian sebelumnya yang menemukan bahwa terdapat pengaruh yang signifikan antara variabel makroekonomi terhadap NPL yang terjadi di perbankan di negara-negara lain. Sehingga penelitian ini menarik untuk melakukan studi lebih lanjut mengenai bagaimana pengaruh variabel makro yang terjadi di Indonesia memengaruhi terjadinya NPL yang terjadi di perbankan di Indonesia. Sehingga dari uraian tersebut dapat diambil kebijakan yang tepat untuk mengurangi tingkat NPL kredit perbankan di Indonesia.

\section{B. Permasalahan}

Variabel makroekonomi yang terjadi dalam perekonomian suatu negara yang terbukti memengaruhi tingkat NPL yang terjadi di perbankan. Perubahan pada perkembangan indikator variabel makroekonomi akan memengaruhi tingkat NPL kredit perbankan di Indonesia. Oleh karena itu, dalam penelitian ini dibahas mengenai bagaimana pengaruh variabel makroekonomi terhadap tingkat NPL kredit perbankan di Indonesia. Hasil akhirnya diharapkan dapat diketahui variabel makroekonomi mana yang paling berpengaruh terhadap tingkat NPL kredit perbankan di Indonesia.

\section{Tujuan}

Penelitian ini bertujuan untuk (1) mengetahui perkembangan NPL perbankan di Indonesia dan (2) mengetahui pengaruh variabel makroekonomi terhadap NPL perbankan di Indonesia. Sehingga berdasarkan hasil penelitian ini diharapkan dapat memberikan masukan kebijakan terkait NPL kredit perbankan yang terjadi dalam perekonomian Indonesia.

\section{KERANGKA TEORI}

\section{A. Definisi Kredit dan NPL}

Kredit dalam arti ekonomi adalah penundaan pembayaran dari prestasi yang diberikan sekarang, baik dalam bentuk barang, uang maupun jasa (Suyatno, 2003). Definisi lain dari kredit adalah suatu reputasi yang dimiliki seseorang yang memungkinkan ia bisa memperoleh uang, barang-barang atau buruh/ tenaga kerja dengan jalan menukarkannya dengan suatu janji untuk membayarnya di suatu waktu yang akan datang (Firdaus, 2004). Sedangkan menurut Kuncoro (2011) mendefinisikan pinjaman/kredit adalah penyediaan uang atau tagihan yang dapat dipersamakan dengan itu, berdasarkan persetujuan atau kesepakatan pinjam-meminjam antara bank dengan pihak lain, yang mewajibkan pihak peminjam untuk melunasi hutangnya setelah jangka waktu tertentu dengan pihak lain, yang mewajibkan pihak peminjam untuk melunasi hutangnya setelah jangka waktu tertentu dengan jumlah bunga, imbalan atau pembagian hasil keuntungan baik bersifat langsung maupun tidak langsung.

Kualitas kredit ditentukan oleh kolektibilitasnya, yaitu lancar tidaknya pembayaran bunga dan pokok pinjaman serta kemampuan debitur yang ditinjau dari keadaan usahanya. Oleh karena itu, kolektibilitas kredit dikategorikan menjadi lancar, kurang lancar, diragukan, dan macet. Disebut lancar apabila tunggakan kredit kurang dari 3 bulan. Digolongkan kurang lancar apabila tunggakan berkisar antara 3-6 bulan. Kategori diragukan bila kredit tersebut tidak memenuhi kriteria kurang lancar namun masih dapat diselamatkan karena nilai agunannya/75 persen dari utang, atau kredit tersebut tidak dapat diselamatkan namun nilai agunannya/100 persen dari utang. Kredit baru disebut macet atau disebut NPL apabila setelah 21 bulan berstatus diragukan, belum ada pelunasan atau penyelamatan kredit, atau kredit yang penyelesaiannya telah diserahkan kepada pengadilan negeri/BPUN, dan kredit yang telah dimintakan pembayaran ganti rugi kepada perusahaan asuransi kredit (Djiwandono, 1994).

Definisi lain dari non performing loan dikemukakan oleh Caprio \& Klingebiel (1999), menurut mereka NPL adalah pinjaman yang untuk jangka waktu tertentu tidak dapat dikembalikan, baik bunga maupun pokoknya untuk jangka waktu kurang lebih 90 hari. Salah satu studi awal mengenai faktor fundamental yang mendorong NPL adalah penelitian yang dilakukan oleh Keeton \& Morris (1987) yang mengambil sampel dari 2.500 bank komersial dengan periode tahun 1979-1985 dan menemukan fakta bahwa sebagian besar proporsi variasi dari kredit yang macet tercermin dari kondisi buruknya perekonomian lokal, dan khususnya tingkat kemiskinan dan kinerja spesifik dari industri pertanian dan energi.

\section{B. Pengaruh Variabel Makroekonomi terhadap NPL Kredit Perbankan}

Lingkungan makroekonomi memiliki pengaruh yang cukup kuat terhadap sektor perbankan. Menurut Festic \& Beko (2008), setiap tekanan dari faktor makroekonomi merupakan sumber risiko sistemik yang memengaruhi kinerja sektor perbankan yang dinyatakan sebagai risiko NPL terhadap total kredit. Fluktuasi dari kegiatan perekonomian (GDP riil) yang saling bergantian antara masa depresi dan masa kemakmuran. Menurut Utari, et al. (2012) pada masa ekspansi ekonomi terjadi peningkatan permintaan agregat yang akan menyebabkan peningkatan pada pertumbuhan kredit perbankan dan tingkat leverage perekonomian. Pada umumnya peningkatan hal tersebut akan diiringi dengan meningkatnya harga 
aset, profitabilitas perusahaan serta ekspektasi konsumen.

Peningkatan permintaan agregat yang melebihi kapasitas perekonomian menjadi alasan dibalik meningkatnya kerentanan terhadap risiko makroekonomi yang disebabkan oleh peningkatan leverage perusahaan dan rumah tangga. Kerentanan tersebut pada akhirnya akan menimbulkan tekanan overheating. Peningkatan konsumsi dan impor yang didorong oleh kredit perbankan akan meningkatkan defisit current account, apabila kondisi ini berlangsung terus menerus akan memicu berkurangnya aliran modal masuk sehingga dapat memengaruhi kondisi keuangan dan sektor perbankan (Utari, et al., 2012).

GDP merupakan nilai pasar dari total semua barang dan jasa yang diproduksi oleh suatu negara dalam satu waktu tertentu. Pertumbuhan GDP menunjukkan peningkatan pendapatan individu dan perusahaan, oleh karena itu kemampuan untuk membayar hutang (kredit) meningkat dan dampaknya NPL menurun. Sebaliknya kondisi penurunan GDP menunjukkan pendapatan individu dan perusahaan yang menurun, sehingga kemampuan untuk membayar hutang (kredit) juga menurun dan NPL mengalami peningkatan (Ahmad \& Bashir, 2013).

Menurut Kasmir (2011), suku bunga dapat diartikan sebagai balas jasa yang diberikan oleh bank yang berdasarkan prinsip konvensional kepada nasabah yang membeli atau menjual produknya. Peningkatan tingkat suku bunga akan memperburuk kualitas dari pinjaman, semakin tingginya biaya hutang membuat debitur semakin sulit membayarkan pinjamannya. Oleh karena itu peningkatan tingkat suku bunga akan meningkatkan tinkat NPL kredit perbankan (Messai \& Jouini, 2013).

Inflasi adalah proses kenaikan harga barangbarang secara terus menerus yang berdampak terhadap penurunan daya beli masyarakat karena secara riil tingkat pendapatannya juga menurun denganasumsibahwatingkat pendapatan masyarakat konstan (Mankiw, 2013). Risiko keuangan juga muncul dikarenakan adanya inflasi, apabila terdapat kenaikan inflasi yang tak terduga akan menyebabkan risiko daya beli. Pada saat terjadi inflasi maka akan menyebabkan beban biaya hidup semakin tinggi karena semakin meningkat biaya akibat hargaharga untuk melakukan konsumsi akan meningkat. Sehingga pada saat terjadinya inflasi maka secara riil pendapatan masyarakat dan perusahaan menurun, sehingga akan menjadi kesulitan bagi debitur untuk mengembalikan pinjaman pada bank.

\section{Studi Empiris}

Akumulasi terjadi NPL menurut Goldstein \& Turner (1996) umumnya disebabkan oleh beberapa faktor, di antaranya adalah kemorosotan ekonomi, ketidakstabilan makroekonomi suatu negara, penurunan perdagangan, suku bunga perbankan yang tinggi, ketergantungan yang berlebih pada pinjaman yang terlalu mahal antarbank, insider lending dan moral hazard. Lebih lanjut Fofack (2005) melakukan penelitian di negara Sub Sahara Afrika yang menemukan pengaruh yang negatif dan signifikan antara GDP per kapita dengan NPL yang terjadi, artinya semakin tinggi tingkat GDP di negara tersebut akan menurunkan tingkat NPL perbankan. Begitu juga dengan real interest rate menunjukkan hubungan yang positif dan signifikan terhadap NPL, yang berarti semakin tinggi tingkat suku bunga perbankan akan memacu peningkatan NPL. Penelitian yang dilakukan oleh Rinaldi \& Arellano (2006) menemukan hasil bahwa peningkatan harga berdampak terhadap peningkatan NPL.

Pengaruh variabel makroekonomi terhadap NPL lebih lanjut telah diteliti oleh Konstantakis, et al. (2016), Viswanadham \& Nahid (2015), Shingjergji (2013), Louzis, et al. (2010) dan Nkusu (2011), hasil penelitian tersebut menekankan bahwa perkembangan perekonomian suatu negara yang memburuk akan dapat meningkatkan kredit perbankan yang macet. Sebaliknya pada saat perekonomian membaik maka tingkat NPL kredit perbankan menjadi semakin menurun. Berdasarkan teori life cycle consumption model yang dikemukakan oleh Modigliani dan Miller serta teori the business cycle theory menyebutkan bahwa pertumbuhan GDP memiliki pengaruh yang negatif dan signifikan terhadap NPL, hal ini dikarenakan pertumbuhan perekonomian membuat pelaku usaha dapat membayar kembali kredit mereka (Hayek, 1941; Salas \& Saurina, 2002; Bangia, et al., 2002; dan Carey, 2002).

Sedangkan Fofack (2005) menemukan bahwa tingkat inflasi yang tinggi menekan masyarakat untuk kesulitan membayar kredit, dampaknya adalah semakin meningkatnya terjadi NPL kredit yang disalurkan oleh perbankan. Berdasarkan data dari Sub Saharan African Countries menemukan bahwa inflasi menyebabkan banyak bank-bank yang kehilangan dana mereka akibat semakin tingginya NPL.

Penelitian ini menguji variabel-variabel makroekonomi yang memengaruhi NPL dengan menggunakan regresi dynamic panel data analysis. Kerangka pemikiran atas penelitian ini disajikan untuk mengarahkan pelaksanakan penelitian dan memudah-kan pembaca dalam memahami alur proses penelitian. Maka dapat dilihat kerangka penelitian dalam penelitian ini dalam Gambar 2.

\section{METODOLOGI}

\section{A. Metode Pengumpulan Data}

Penelitian ini menggunakan metode kuantitatif dalam menganalisis pengaruhvariabel makroekonomi terhadap NPL kredit perbankan. Berdasarkan literatur 


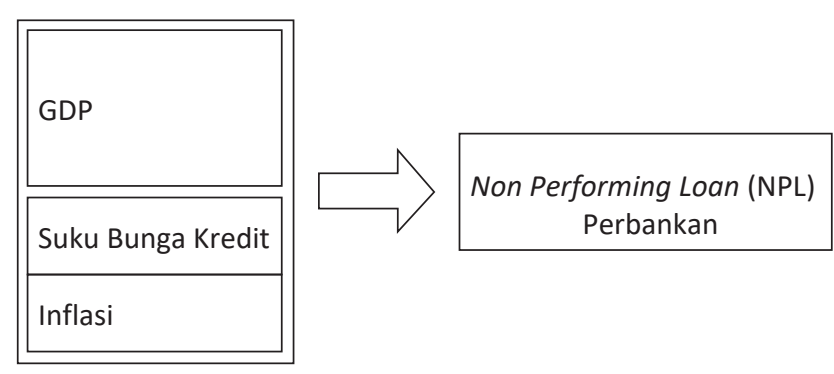

Gambar 2. Kerangka Konsep Penelitian

terbaru dalam studi panel yang dilakukan oleh Salas \& Saurina (2002), Athanasoglou, et al. (2008) dan Merkl \& Stolz (2009) terhadap perbankan, Calderon \& Chong (2001), Cheng \& Kwan (2000), Beck \& Levine (2004), Santos-Paulino \& Thirwall (2004) dan Carstensen \& Toubal (2004) penelitian terhadap makroekonomi maka penelitian ini menggunakan pendekatan dinamik. Pendekatan dinamik diadopsi untuk menjelaskan persistensi waktu dalam struktur NPL. Penelitian ini merupakan penelitian replikasi pengembangan (extended replication) atas penelitian sebelumnya yang telah dilakukan oleh Louzis, et al., (2010). Pengembangan dalam penelitian ini adalah berkaitan dengan penggantian variabel yang digunakan yang memengaruhi NPL. Hal lain yang membedakan dengan penelitian sebelumnya adalah perubahan sedikit terhadap persamaan yang digunakan dan dalam penelitian juga menggunakan 9 sektor ekonomi yang ada di Indonesia berdasarkan data dari tahun 2006-2014.

\section{B. Metode Penelitian}

Hubungan di antara variabel-variabel ekonomi pada kenyataan banyak yang bersifat dinamis. Analisis panel data dinamis dapat digunakan pada model yang bersifat dinamis yang melibatkan variabel lag dependent sebagai variabel regresor di dalam model. Keuntungan menggunakan panel data dinamis adalah bahwa panel data dinamis dapat mengkaji mengenai analisis penyesuaian dinamis (dynamic of adjustment) (Baltagi, 2005). Ciri utama dari spesifikasi panel data dinamis adalah dimasukkannya lag variabel dependent ke dalam variabel independent, yaitu:

$$
\begin{aligned}
y_{i t}= & \alpha y_{i t-1}+\beta(L) X_{i t}+\eta_{i}+\varepsilon_{i t}, \ldots \ldots \ldots \ldots . . . . . . . . \\
& \alpha \mid<1, i=1, \ldots \ldots, t=1, \ldots \ldots, T
\end{aligned}
$$

Di mana i dan t menandakan cross sectional dan dimensi waktu dengan sampel masing-masing panel, $\mathrm{y}_{\text {it }}$ adalah turunan pertama dari NPL, $\beta(L)$ adalah lag polynomial vektor, $\mathrm{x}_{\mathrm{it}}$ adalah variabel independent, $\mathrm{n}_{\mathrm{i}}$ adalah individual yang tidak diamati dari efek spesifik masing-masing bank dan $\varepsilon_{i t}$ adalah error term.

Sebagai variabel lag dependen, $y_{i t-1}$ memiliki hubungan erat dengan efek spesifik dari masing-masing bank, $\eta_{i}$ dengan menggunakan pendekatan teknik estimasi Ordinary Least Square (OLS) akan menghasilkan parameter regresi yang bias dan inkonsisten. Pendekatan method of moments dapat digunakan untuk mengatasi masalah bias dan inkonsistensi. Setidaknya ada dua alasan yang mendasari, pertama, GMM merupakan common estimator dan memberikan kerangka yang lebih bermanfaat untuk perbandingan dan penilaian. Kedua, GMM memberikan alternatif yang sederhana terhadap estimator lainnya, terutama terhadap maximum likelihood. Sehingga persamaan (1) dilakukan estimasi dengan menggunakan Generalized Method of Moments (GMM) sebagaimana yang digunakan oleh Arellano \& Bond (1991) dan secara umum dipakai oleh Arellano \& Bover (1995) dan Blundell \& Bond (1998). Estimasi menggunakan GMM yang dilakukan oleh Arellano and Bond (1991) didasarkan pada transformasi turunan pertama dari persamaan (1) dan penghapusan efek spesifik dari masing-masing bank:

$$
\Delta \mathrm{y}_{i t}=\alpha \Delta y_{i t}-1+\beta(L) \Delta X_{i t}+\Delta \varepsilon_{i t}
$$

Di mana $\Delta$ adalah simbol dari turunan pertama. Dalam persamaan (2), variabel lag dependen, $\Delta \mathrm{y}_{\mathrm{it}-1}$ ini berkorelasi dengan jangka waktu error. $\Delta \varepsilon_{\mathrm{it}}$ menandakan bias dalam estimasi model. Namun, $\mathrm{y}_{\mathrm{it}-2}$ yang diharapkan berkorelasi dengan $\Delta \mathrm{y}_{\mathrm{it}-1}$ tetapi tidak berkorelasi dengan $\Delta \varepsilon_{\text {it }}$ untuk $\mathrm{t}=3, \ldots ., \mathrm{T}$, dapat digunakan sebagai instrumen dalam estimasi persamaan (2), mengingat bahwa $\varepsilon_{\text {it }}$ tidak berkorelasi secara serial. Hal ini menunjukkan bahwa lag 2 atau lebih dari variabel memenuhi moment kondisi saat:

$$
\mathrm{E}\left[\mathrm{Y}_{\mathrm{it}}-{ }_{s} \Delta \varepsilon_{\mathrm{it}}\right]=0 \text {. }
$$$$
\text { untuk } \mathrm{t}=3, \ldots, \mathrm{T} \text { dan } \mathrm{s} \geq 2
$$

Sumber kedua bias berasal dari endogenitas yang kemungkinan dari variabel penjelas dan resultan dari korelasi dengan error. Dalam kasus variabel eksogen yang ketat, nilai dari varibel penjelas yang tidak berkorelasi dengan error, menyiratkan kondisi moment sebagai berikut:

$$
\mathrm{E}\left[\mathrm{y}_{\mathrm{it}}-{ }_{\mathrm{s}} \Delta \varepsilon_{\mathrm{it}}\right]=0
$$

untuk $\mathrm{t}=3, \ldots, \mathrm{T}$ dan untuk semua $\mathrm{s}$

Exogenous assumptions yang ketat dan invalid adanya cadangan yaitu ketika $\left[\mathrm{y}_{\mathrm{it}}-{ }_{s} \Delta \varepsilon_{\mathrm{it}}\right] \neq 0$ untuk $\mathrm{t}<$ s. Untuk satu persamaan dari variabel eksogen yang lemah atau variabel penjelas yang telah ditentukan, hanya terjadi pada saat ini dan nilai lag dari $\mathrm{X}_{\mathrm{it}}$ adalah instrumen valid dapat digunakan kondisi moment sebagai berikut:

$\mathrm{E}\left[\mathrm{y}_{\mathrm{it}}-{ }_{\mathrm{s}} \Delta \varepsilon_{\mathrm{it}}\right]=0$

$$
\text { untuk } \mathrm{t}=3, \ldots, \mathrm{T} \text { dan untuk } \mathrm{s} \geq 2
$$

Untuk menjawab pertanyaan penelitian ini, maka penelitian menggunakan model yang digunakan oleh 
Tabel 1. Data dan Variabel untuk Estimasi

\begin{tabular}{ll}
\hline \multicolumn{1}{c}{ Variabel } & \multicolumn{1}{c}{ Sumber Data } \\
\hline Non Performing Loan & Bank Indonesia (BI) \\
\hline Gross Domestic Product & Badan Pusat Statistik (BPS) \\
\hline Inflasi & Badan Pusat Statistik (BPS) \\
\hline Suku Bunga Kredit & Bank Indonesia (BI) \\
\hline
\end{tabular}

Louzis, et al., (2010) dengan perbedaan pada sampel dan periode waktu terhadap objek penelitian. Penggunaan model ini digunakan untuk meneliti pengaruh variabel makroekonomi terhadap tingkat NPL perbankan di Indonesia. Sehingga persamaan yang digunakan (1) dapat dituliskan kembali menjadi:

$$
\begin{aligned}
& \Delta N L^{h}{ }_{i t}=\alpha \Delta N P L^{h}{ }_{i t-1}+\Sigma_{j=1}^{2} \beta_{i j}^{h} \Delta G D P_{t-j}+\sum_{j=1}^{2} \beta_{2 j}^{h} I N F L_{t} \\
& +\sum_{\mathrm{j}=1}^{2} \beta_{3 \mathrm{j}}^{\mathrm{h}-1} \Delta \mathrm{SB}_{\mathrm{t}-\mathrm{j}}+\varepsilon_{\mathrm{it}}^{\mathrm{h}}
\end{aligned}
$$

Pada persamaan (6) $\mathrm{h}$ menunjukkan sektor ekonomi (9 sektor perekonomian di Indonesia), $\triangle N P L^{h}$ it adalah turunan pertama dari NPL, $\triangle G D P_{t-1}$ adalah GDP riil, Infl $\left.\right|_{\mathrm{t}-\mathrm{j}}$ adalah inflasi, $\Delta \mathrm{SB}_{\mathrm{t}-\mathrm{j}}$ adalah suku bunga kredit. Berdasarkan persamaan (6) dilakukan estimasi regresi untuk menjawab pertanyaan penelitian ini berdasarkan data dan variabel dengan observasi tahun 2006-2014.

Analisis model pada persamaan (6) dilakukan dengan menggunakan panel data dinamis pendekatan First Difference Generalized Method of Moment (FDGMM). Kriteria pemeriksaan model yang dilakukan adalah validitas dan konsistensi model. Uji Sargan untuk overidentifying restriction merupakan suatu pendekatan untuk mendeteksi masalah validitas instrumen. Hipotesis nol menyatakan bahwa tidak ada masalah dengan validitas instrumen (instrumen valid), artinya variabel instrumen yang digunakan tidak berkorelasi dengan error pada persamaan FD-GMM. Nilai statistik uji Sargan dihitung sebagai berikut:

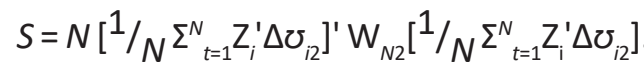

Pada hipotesis nol, nilai statistik tersebut mengikuti sebaran Chi-square $\mathrm{X}_{\mathrm{q}}{ }^{2}$ dengan $\mathrm{q}$ menyatakan jumlah instrumen dikurangi jumlah parameter yang digunakan dalam model.

\section{HASIL DAN PEMBAHASAN}

A. Perkembangan NPL Kredit Perbankan di Indonesia

Perkembangan kredit dalam bentuk rupiah yang disalurkanoleh perbankan menunjukkan pertumbuhan yang pesat pasca Pakto tahun 1988, terutama tahun 1989-1991. Pada masa ini terjadi booming akan kredit yang disalurkan oleh perbankan yang disebabkan oleh kebijakan moneter yang ekspansif. Akan tetapi Gebrakan Sumarlin, yang menandai era kebijakan moneter ketat serta Pakfeb tahun 1991, yang menggariskan prinsip prudential banking practice, yang menyebabkan terjadinya perlambatan ekspansi kredit yang cukup berarti. Namun, pada lima tahun terakhir pada Gambar 3 menunjukkan dominasi bank swasta nasional yang gencar memberikan kredit mampu mengalahkan dominasi posisi kredit yang disalurkan oleh Bank Persero. Demikian pula geliat ekspansi bank asing dan campuran yang gencar untuk melakukan penetrasi kredit di Indonesia.

Dilihat secara sektoral, berdasarkan Gambar 4 selama 5 tahun terakhir sektor yang paling banyak mendapat kucuran kredit adalah sektor perdagangan, hotel, dan restoran. Peringkat kedua dipegang oleh sektor industri pengolahan. Sektor industri terutama tekstil, sandang, kulit, pengolahan bahan kimia, batu bara, hasil minyak bumi, karet, dan plastik. Peringkat ketiga dan seterusnya berturut-turut adalah sektor keuangan, sektor jasa, dan lain-lain. Sedangkan dari sisi rata-rata pertumbuhan per tahun selama 5 tahun terakhir perkembangan kredit perbankan berdasarkan sektor ekonomi paling tinggi adalah ratarata pertumbuhan sektor jasa. Pertumbuhan kredit perbankan sektor jasa meningkat secara signifikan pada tahun 2006 sampai dengan tahun 2014. Peringkat kedua dan seterusnya berturut-turut adalah sektor listrik, gas, dan air bersih; sektor pertambangan dan penggalian; sektor pengangkutan dan komunikasi; sektor pertanian, peternakan, kehutanan, dan perikanan; sektor industri pengolahan; sektor perdagangan, hotel, dan restoran; sektor konstruksi, dan terakhir sektor keuangan, real estate, dan jasa perusahaan.

Secara keseluruhan berdasarkan Gambar 4 dapat disimpulkan bahwa terjadi kenaikan jumlah kredit yang disalurkan oleh perbankan terhadap seluruh sektor ekonomi. Sebagai contoh jumlah kredit yang disalurkan terhadap sektor industri yang pada tahun 2006 berjumlah Rp104.713 miliar meningkat 315 persen pada tahun 2014 menjadi Rp435.079 miliar. Peningkatan jumlah kredit ini tentu disebabkan aktivitas perekonomian yang meningkat dalam sektor-sektor ekonomi. Sektor-sektor ekonomi yang mengalami perkembangan dan pertumbuhan

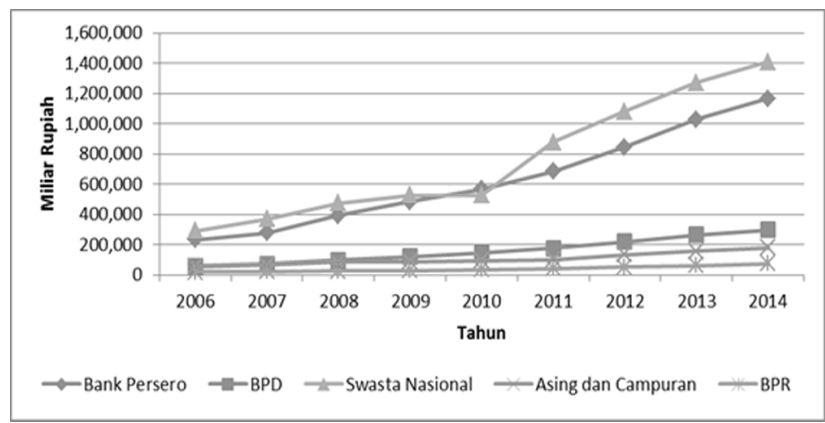

Sumber: Bank Indonesia (berbagai edisi, diolah).

Gambar 3. Posisi Pinjaman dalam Rupiah yang Diberikan Perbankan Tahun 2006-2014 


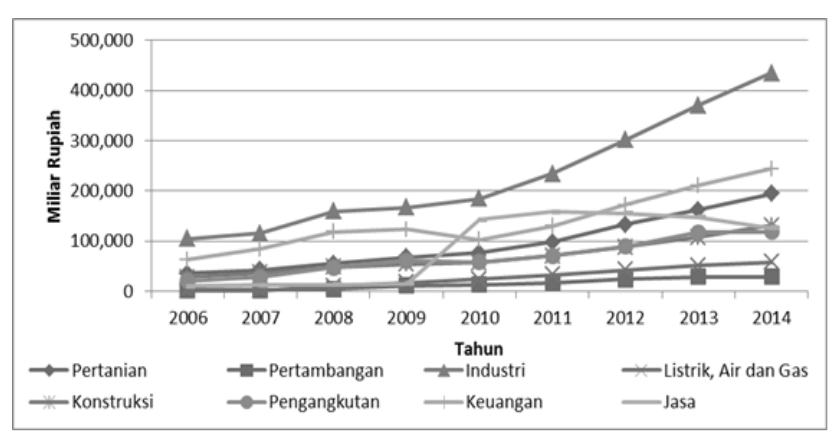

Sumber: Bank Indonesia (berbagai edisi, diolah).

Gambar 4. Posisi Kredit dalam Rupiah yang Disalurkan oleh Perbankan menurut 8 Sektor Ekonom Periode Tahun 2006-2014

tentu membutuhkan dana baik untuk modal kerja maupun investasi untuk mengembangkan usaha di masing-masing sektor. Kebutuhan dana inilah yang oleh bank sebagai lembaga intermediasi keuangan, yang menghimpun dana dari masyarakat dan menyalurkannya kembali ke sektor-sektor ekonomi.

Namun kondisi pada saat jumlah kredit yang disalurkan oleh perbankan terhadap sektor-sektor perekonomian semakin meningkat setiap tahun, satu hal yang juga perlu diperhatikan adalah NPL yang terjadi. Pada Gambar 5 terlihat dari 8 sektor perekonomian di Indonesia, sektor perdagangan, hotel dan restoran adalah sektor yang mengalami peningkatan tren NPL yang meningkat cukup tinggi dibandingkan sektor lainnya setiap tahunnya. Hal ini tentu menjadi catatan bagi dunia perbankan untuk semakin meningkatkan prinsip prudent dalam menyalurkan kredit terhadap sektor ini. Peningkatan kredit yang cukup tinggi yang disalurkan kepada sektor ini, dilihat dari sisi NPL ternyata sektor ini juga mengalami peningkatan tren NPL. Sektor lain yang juga mengalami peningkatan tren NPL adalah kontruksi, sementara sektor yang mengalami tren yang menurun adalah sektor industri pengolahan.

Fakta yang cukup menarik ditunjukkan oleh Gambar 5. Berdasarkan analisis grafik kita bisa melihat dengan

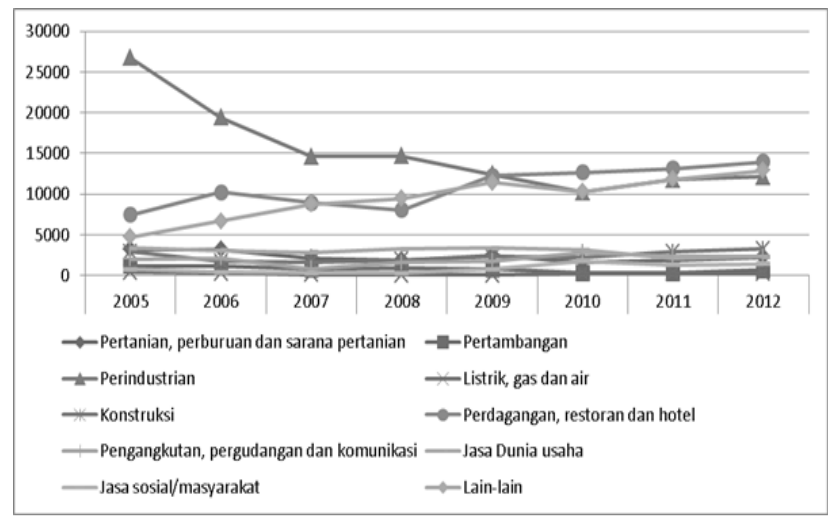

Sumber: Bank Indonesia (berbagai edisi, diolah).

Gambar 5. Perkembangan NPL menurut Sektor Ekonomi Periode Tahun 2005-2012 jelas bahwa kondisi makroekonomi yang dialami oleh Indonesia pada setiap sektor perekonomian ternyata memiliki keterkaitan pola dengan NPL yang terjadi di setiap sektor. Salah satu indikator kondisi makro tersebut adalah GDP, pola pertumbuhan GDP memiliki tren yang berlawanan dengan pertumbuhan NPL yang terjadi di setiap sektor perkonomian di Indonesia. Sektor perdagangan, hotel dan restoran pada periode tahun 2008 sampai dengan 2012 sebagai contoh, terjadi peningkatan pertumbuhan GDP di sektor ini maka akan mengakibatkan penurunan NPL yang terjadi di sektor ini pada periode yang sama. Hal ini berarti menunjukkan kepada kita bahwa pertumbuhan GDP pada sektor ini dapat menunjukkan perbaikan pertumbuhan ekonomi pada sektor ini mampu menurunkan NPL sektor ini. Dengan kata lain hal ini sejalan dengan kesimpulan banyak penelitian yang telah dilakukan sebelumnya, salah satunya penelitian yang dilakukan oleh Bofondi \& Ropele (2011) yang mengatakan bahwa kondisi makroekonomi pada umumnya memengaruhi kualitas kredit yang diberikan oleh perbankan.

\section{B. Pengaruh Makroekonomi terhadap NPL}

Berdasarkan hasil penelitian ini maka didapatkan hasil estimasi pada Tabel 2. Dapat diamati bahwa koefisien hasil estimasi memiliki tanda yang kompetibel dengan intuisi ekonomi dan argumen teori seperti yang telah diutarakan pada bagian sebelumnya.

Berdasarkan statistik uji Sargan, hipotesis nol bahwa variabel overidentifiying restrictions adalah valid, dengan p-value 0,318 artinya instrumen yang digunakan valid untuk digunakan sebagai variabel dalam regresi ini. Uji konsistensi model dilakukan dengan melihat tingkat signifikansi $A B m_{1}$ yang signifikan pada level 5 persen dan $A B m_{2}$ yang tidak signifikan pada level 5 persen, artinya tidak ada korelasi serial atau model konsisten.

Berdasarkan regresi maka hasil penelitian ini menunjukkan pengaruh yang negatif dan signifikan

Tabel 2. Estimasi Non Performing Loan Perbankan pada Sektor Ekonomi dengan Metode Panel Dinamis FD-GMM

\begin{tabular}{lrrr}
\hline \multicolumn{1}{c}{ Variables } & $\begin{array}{c}\text { Estimated } \\
\text { Coefficients }\end{array}$ & $\begin{array}{c}\text { Standard } \\
\text { Error }\end{array}$ & P-value \\
\hline $\mathrm{NPL}_{\mathrm{t}-1}$ & 0,506 & 0,067 & 0,000 \\
\hline Gross Domestic Product & $-0,012$ & 0,182 & 0.027 \\
\hline Suku Bunga & 0,571 & 0,216 & 0.008 \\
\hline Inflasi & 0,385 & 0,157 & 0,015 \\
\hline $\mathrm{AB} m_{1}$ & $-1,698$ & - & 0,001 \\
\hline $\mathrm{AB} m_{2}$ & $-1,020$ & - & 0,036 \\
\hline Sargan Test & 13,818 & - & 0,318 \\
\hline
\end{tabular}

Sumber: Hasil pengolahan data menggunakan Stata 10. 
antara GDP dengan NPL dengan taraf signifikansi 95 persen. Pengaruh salah satu makroekonomi yang diteliti GDP yang dapat diartikan berarti setiap kenaikan 1 persen pertumbuhan ekonomi justru akan mengurangi tingkat kredit macet/NPL yang terjadi sebesar 0,012 persen. Maka hal ini dapat diartikan bahwa pertumbuhan ekonomi yang terjadi harus semakin dipacu agar dapat menurun NPL yang terjadi di sektor perekonomian. Dengan semakin meningkatnya GDP berarti dengan kata lain terjadi pertumbuhan ekonomi pada sektorsektor ekonomi di Indonesia. Pertumbuhan ekonomi di sektor-sektor ekonomi tersebut yang memberikan kemampuan untuk sektor-sektor ekonomi yang ada untuk dapat melunasi kredit yang harus dilunasinya sebagai kewajiban.

Hasil penelitian ini sejalan dengan dengan penelitian empiris yang dilakukan oleh penelitian sebelumnya oleh Salas \& Saurina (2002). Salas \& Saurina melakukan penelitian kombinasi antara variabel makroekonomi dan mikroekonomi terhadap perbankan Spanyol untuk periode tahun 19851997. Mereka menemukan pengaruh yang negatif dan signifikan efek pertumbuhan GDP terhadap NPL, juga menyimpulkan bahwa perkembangan makroekonomi yang positif memberikan kemampuan agen-agen ekonomi untuk dapat melunasi hutanghutang mereka.

Espinoza \& Prasad (2010) dengan menggunakan metode panel dinamik menunjukkan bahwa rasio NPL semakin meningkat dengan semakin menurunnya pertumbuhan ekonomi yang terjadi. Penelitian yang dilakukan oleh Louzis, et al., (2010) dengan mengunakan data dari bank di Yunani juga menunjukkan pengaruh yang negatif dan signifikan dari pertumbuhan GDP terhadap rasio NPL yang terjadi. Bonilla (2012) melakukan penelitian dengan menggunakan data negara Spanyol dan Itali, menemukan bahwa GDP secara statistik memiliki pengaruh yang signifikan terhadap tingkat NPL di kedua negara tersebut. Berdasarkan data dari 75 negara di Eropa, juga menunjukkan hasil yang sama, bahwa pertumbuhan GDP memiliki pengaruh yang signifikan terhadap terhadap rasio NPL (Beck, et al., 2013).

Berdasarkan hasil penelitian ini menunjukkan bahwa koefisien dari suku bunga menunjukkan tanda positif dan signifikan. Hal ini menunjukkan hubungan yang searah antara suku bunga dengan rasio NPL. Artinya setiap penurunan 1 persen suku bunga dapat menurunkan rasio NPL di berbagai sektor ekonomi sebesar 0,571 persen. Dengan kata lain semakin tinggi tingkat suku bunga maka dapat meningkatkan tingginya rasio NPL dari berbagai sektor pereknomian. Tingginya tingkat suku bunga perbankan dapat mengurangi kemampuan debitur dari sektor-sektor perekonomian dalam membayar pinjamanya. Ketidakmampuan debitur dari berbagai sektor perekonomian dalam membayar pinjamannya ini akan dapat menyebabkan meningkatnya NPL perbankan.

Hasil penelitian senada dengan penelitian Cihak (2007) yang memberikan konklusi bahwa ketika suku bunga naik akan mengurangi stabilitas perbankan yang ditandai salah satunya oleh peningkatan kredit macet dalam bentuk NPL. Pada saat kondisi krisis perekonomian di Indonesia pada tahun 1997/1998 telah memberikan pelajaran yang cukup mendalam bagi perbankan Indonesia. Kondisi pada saat itu di mana suku bunga perbankan sangat tinggi, bahkan suku bunga pinjaman mencapai 33 persen. Tingginya tingkat suku bunga di dalam negeri dibiarkan oleh pemerintah pada waktu itu ditujukan untuk menahan pelarian dana ke luar negeri (Tarmidi, 1999). Dampak dari tingkat suku bunga yang tinggi ini adalah meningkatnya jumlah cicilan kredit yang harus dibayar oleh debitur. Peningkatan ini pada ujungnya menyebabkan debitur kesulitan untuk memenuhi kewajibannya membayar kredit. Akibatnya kebijakan suku bunga yang tinggi pada saat krisis tahun 1997/1998 mengakibatkan rasio NPL yang meningkat tinggi dari semua sektor perekonomian.

Mengingat sejarah pada waktu krisis tersebut, maka sudah selayaknya perbankan menetapkan suku bunga pinjaman yang wajar. Akan tetapi keadaan yang terjadi adalah sistem perbankan yang menetapkan spread yang cukup tinggi antara BI rate sebagai suku bunga acuan perbankan dengan suku bunga kredit yang diberikan oleh perbankan kepada berbagai sektor perekonomian. Bahkan untuk beberapa sektor perekonomian perbankan menerapkan suku bunga yang yang tidak sama untuk sektor perkonomian.

Sistem perbankan yang tidak efesien ditunjukkan dengan tingginya perbedaan antara suku bunga pinjaman dan deposito. Hal demikian menguntungkan pihak perbankan, tetapi sangat merugikan perekonomian. Alasannya, suku bunga pinjaman yang sangat dibutuhkan untuk pergerakan perekonomian tetap berada pada level yang cukup tinggi, meski bunga deposito sudah cukup rendah. Tingkat profitabilitas bank yang harus tinggi harus dibayar dengan lemahnya kemampuan bank dalam menyalurkan kredit. Fungsi intermediasi yang sangat dibutuhkan untuk menggerakkan perekonomian harus dikorbankan, sementara keuntungan dinikmati secara leluasa oleh dunia perbankan.

Tingkat keuntungan sektor perbankan yang tinggi telah dibayar (trade off) dengan tingginya suku bunga kredit. Fakta paling kasat mata ini menunjukkan perbankan bukan saja gagal mendorong pembangunan inklusif, tetapi juga gagal mendorong sektor riil untuk bergerak lebih cepat menyerap banyak tenaga kerja serta mengurangi tingkat kemiskinan. Kegagalan 
perbankan yang sangat oligopolis dapat dilihat dari sisi penguasaan aset dan pangsa pasar. Hanya ada lima bank besar yang menguasai sekitar 50 persen aset perbankan dan 70 persen pasar deposito. Dari sisi pasar deposito, hanya sekitar 1,3 persen nasabah yang memegang sekitar 74 persen dana pihak ketiga di perbankan Indonesia. Karena itu, perbankan cenderung tidak responsif terhadap kebijakan moneter Bank Indonesia. Dengan kata lain transmisi kebijakan moneter di Indonesia cenderung gagal atau tidak bekerja maksimal.

Hasil penelitian ini menunjukkan pengaruh yang positif dan signifikan antara inflasi yang terjadi dengan rasio NPL. Setiap peningkatan 1 persen inflasi maka akan menyebabkan peningkatan rasio NPL sebesar 0,385 persen. Dengan kata sederhana setiap peningkatan inflasi maka akan menyebabkan peningkatan rasio NPL kredit dari berbagai sektor perekonomian. Kenaikan harga Bahan Bakar Minyak (BBM) dan kenaikan harga tarif listrik sebagai contoh akan mengakibatkan kenaikan inflasi. Dan dampak yang paling dirasakan oleh para pelaku usaha dari berbagai sektor perekonomian adalah meningkatnya beban usaha atau pengeluaran yang mereka harus keluarkan akibat naiknya tarif listrik dan naiknya harga BBM. Kenaikan beban usaha yang dirasakan sedangkan pendapatan tetap maka menyebabkan pelaku usaha tersebut kesulitan memenuhi kewajiban mereka membayar cicilan kredit kepada bank. Untuk itu diperlukan peran serta berbagai pihak termasuk pemerintah sebagai pemegang kekuasaan fiskal agar dalam mengeluarkan kebijakan kenaikan harga harus mengakomodir dan menyerap juga kepentingan pelaku usaha dari berbagai sektor perekonomian. Sehingga kenaikan harga yang terjadi tidak memberikan dampak yang terlalu parah terhadap pelaku usaha.

Hasil penelitian ini sejalan dengan penelitian yang dilakukan oleh Hoggarth, et al. (2005), dengan menggunakan data dari tahun 1988-2004 terhadap perbankan Inggris menemukan bahwa terjadi peningkatan rasio kredit macet akibat peningkatan inflasi yang terjadi. Hasil penelitian ini senada juga dengan penelitian yang dilakukan oleh Babaoucek \& Jancar (2005) menemukan hasil bahwa terjadi pengaruh yang positif dari inflasi dan tingkat pengangguran terhadap NPL yang terjadi. Lebih lanjut Hernando \& Vilanueva (2004) menjelaskan bahwa setiap terjadi peningkatan inflasi juga berdampak terhadap peningkatan rasio NPL kredit untuk perumahan. Ouhibi \& Hammami (2015) juga menemukan bahwa tingkat inflasi yang terjadi memiliki pengaruh yang negatif dan signifikan terhadap NPL. Pengaruh inflasi yang positif terhadap NPL dari berbagai sektor juga dapat terlihat pada Gambar 7. Pada gambar tersebut terlihat jelas bahwa dari berbagai sektor perekonomian inflasi yang terjadi memiliki pengaruh yang positif terhadap NPL.

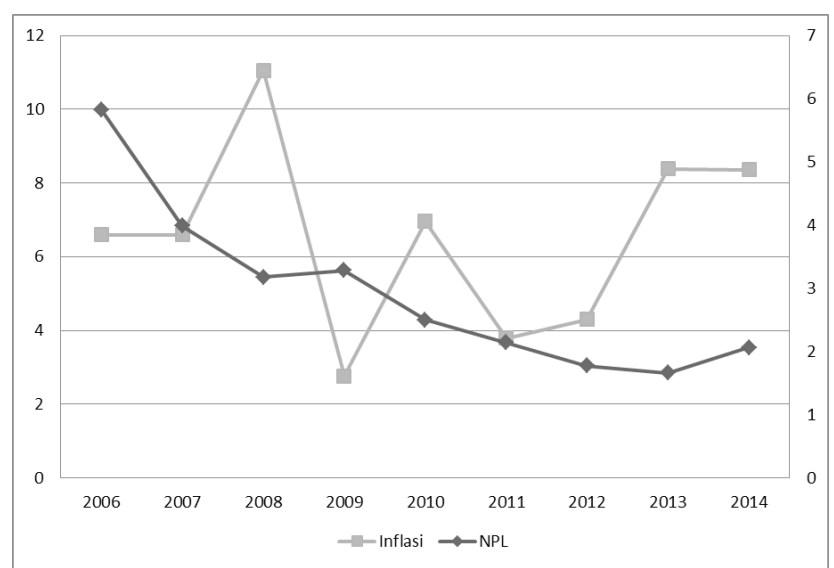

Sumber: Bank Indonesia dan Badan Pusat Statistik, berbagai edisi (diolah).

Gambar 7. Inflasi dan NPL Periode Tahun 2006-2014

\section{SIMPULAN DAN SARAN}

\section{A. Simpulan}

Perkembangan kredit pada periode penelitian tahun 2006-2016 mengalami tren yang meningkat. Peningkatan kredit ini pada saat yang bersama diikuti oleh peningkatan tren NPL. Dari 9 sektor perekonomian, ternyata sektor perdagangan, hotel dan restoran adalah sektor yang mengalami tren peningkatan NPL perbankan yang cukup tinggi dibandingkan dengan sektor perekonomian lainnya. Sementara itu sektor perekonomian yang mengalami tren peningkatan NPL perbankan yang cukup rendah bahkan mengalami tren penurunan adalah sektor perindustrian.

Hasil pengolahan data pada penelitian ini, penulis mendapatkan beberapa kesimpulan yaitu berdasarkan hasil analisis regresi panel dinamik ternyata terhadap NPL perbankan dari berbagai sektor perekonomian. Hal ini menunjukkan semakin membaiknya kondisi makroekonomi suatu negara yang ditandai dengan semakin meningkatnya GDP maka semakin menurun rasio NPL perbankan dari berbagai sektor perekonomian yang terjadi. Penelitian ini juga menemukan hasil bahwa tingkat suku bunga dan inflasi memiliki pengaruh yang positif dan signifikan. Hasil ini memberikan pengertian bahwa semakin tinggi tingkat suku bunga pinjaman yang diberikan oleh perbankan maka akan semakin meningkatkan rasio NPL perbankan dari berbagai sektor. Demikian juga halnya dengan inflasi, semakin terjadi peningkatan harga-harga yang dapat memicu terjadinya inflasi, maka hal tersebut dapat mengakibatkan terjadinya peningkatan rasio NPL perbankan dari berbagai sektor.

\section{B. Saran}

Pengaruh variabel makroekonomi yang memiliki pengaruh yang signifikan terhadap rasio NPL perbankan di Indonesia harus dapat diambil tindak lanjut oleh berbagai stakeholder terkait demi menjaga tingkat rasio NPL kredit perbankan pada tingkat yang relatif rendah. Hendaknya Pemerintah harus mengeluarkan kebijakan 
yang memperhatikan dampak terhadap perubahan variabel makroekonomi, terutama yang terkait dengan GDP dan inflasi. Pemerintah harus dapat menstimulus peningkatan GDP, karena GDP yang meningkat dapat mengurangi tingkat NPL perbankan yang terjadi. Selanjutnya, pemerintah dirasa perlu untuk menjaga tingkat harga pada level yang relatif rendah dan stabil.

Sedangkan Bank Indonesia hendaknya harus dapat menjaga tingkat suku bunga acuan pada tingkat yang relatif rendah dan stabil. Tingkat suku bunga yang relatif rendah dan stabil maka dapat membuat tingkat rasio NPL menurun. Dengan demikian perpaduan antara kebijakan fiskal dan moneter yang dikeluarkan dapat bersinergi. Hal ini diperlukan agar kebijakan fiskal dan moneter yang dikeluarkan oleh pemerintah dan Bank Indonesia harus saling mendukung. Sehingga kebijakan yang dikeluarkan pemerintah tidak kontraproduktif terhadap kebijakan moneter yang dikeluarkan oleh BI dalam mendukung peningkatan kredit dan menjaga NPL pada level yang rendah.

\section{DAFTAR PUSTAKA}

\section{Buku}

Baltagi, B. H. (2005). Analysis of panel data. England: John Wiley \& Son, Ltd.

Firdaus, R. (2004). Manajemen perkreditan bank umum: Teori, masalah, kebijakan dan aplikasinya lengkap dengan analis kredit. Bandung: Alfa Beta.

Hayek, F. A. (1941). The pure theory of capital. Chicago: University of Chicago Press.

Kasmir. (2011). Manajemen perbankan. Jakarta: PT Raja Grafindo Persada.

Kuncoro, M. (2011). Manajemen perbankan: Teori dan aplikasi. Yogyakarta: BPFE.

Mankiw, N. G. (2013). Principle of macro-economics. Singapore: Cengate.

Rose, P. S. \& Hudgins, S. C. (2005). Bank management and financial service. New York: Mc.Graw Hill Education.

Suyatno, T. (2003). Lembaga keuangan. Jakarta: Gramedia.

\section{Jurnal}

Abid, L., Quertani, M. N., \& Zouari Ghorbel, S. (2014). Macroeconomic and bank-spesific determinants of household's non performing loans in Tunisia: A dynamic panel data. Procedia Economics and Finance, 13(1), 58-68.

Ahmad, F. \& Bashir, T. (2013). Explanatory power of macroeconomic variable as determinants of NPL: Evidence from Pakistan. World Applied Sciences Journal, 22(1), 243-255.

Arellano, M. \& Bond, S. (1991). Some test of specification for panel data: Monte Carlo evidence and an application to employment equations. The Review of Economic Studies, 58(2), 277-297.

Arellano, M. \& Bover, O. (1995). Another look at the instrumental variable of error-components models. Jounal of Econometrics, 68, 29-51.

Athanasoglou, P. P., Brissimis, S. N., \& Delis, M. D. (2008). Bank-specific, industry-specific and macroeconomic determinants of bank profitability. Journal of Banking and Finance, 26, 929-951.

Bangia, A., Diebold, F. X., Kronimus, A., Schagen, C., \& Schuermann, T. (2002). Ratings migration and the business cycle, with application to credit portfolio stress testing. Journal of Banking and Finance, 26, 445-474.

Beck, T. \& Levin, R. (2004). Stock markets, banks, and growth: Panel evidence. Journal of Banking and Finance, 28(3), 423-442.

Blundell, R. \& Bond, S. (1998). Initial conditions and moment conditions in dynamic panel data models. Journal of Econometrics, 87, 115-143.

Calderon, C. \& Chong, A. (2001). External sector and income inequality in interdependent economies using a dynamic panel data approach. Economic Letters, 71, 225-231.

Carey, M. (2002). A guide to choosing absolute bank capital requirements. Journal of Banking and Finance, 26, 929-951.

Carstensen, K. \& Toubal, F. (2004). Foreign direct investment in Central and Eastern European Countries: A dynamic panel analysis. Journal of Comparative Economics, 32, 3-22.

Cheng, L. K. \& Kwan, Y. K. (2000). What are the determinants of the location of foreign direct investment? The Chinese experience. Journal of International Economics, 51, 379-400. 
Djiwandono, J. S. (1994). Permasalahan kredit dalam kerangka pembiayaan pembangunan nasional. Economic Journal of Emerging Markets, Vol. 4, 3-14.

Festic, M. \& Beko, J. (2008). The Banking sector and macroeconomic performance in Central European Economies. Czech Journal of Economics and Finance, 3(58), 131-151.

Hernando, I. \& Vilanueva, E. (2004). The recent slowdown in bank lending in Spain: Are supplyside factor relevant. SERIEs, 5(2), 245-285.

Jolevska, E. D. \& Andovski, I. (2014). Non performing loan in the Banking Systems of Serbia, Croatia and Macedonia: Comparative analysis. Ekohomhka, 61(1), 115-130.

Konstantakis, K. N., Michaelides, P. G., \& Vouldis, A. T. (2016). Non performing loan (NPLs) in a crisis economy: Long-run equlibrium analysis with a real time VEC model for Greece (20012015). Physica A: Statiscal Mechanics and its applications, 451(1), 149-161.

Merkl, C. \& Stolz, S. (2009). Banks regulatory buffers, liquidity networks and monetary policy transmission. Applied Economis, 41, 2.013-2.024.

Messai, A. S. \& Jouini, F. (2013). Micro and macro determinants of NPL. International Journal of Economics and Finance Issues, 3(4), 852-860.

Ouhibi, S. \& Hammami, S. (2015). Determinant of NPL in the South Mediterranean countries. International Journal of Accounting and Economics Studies, 3(1), 50-53.

Quangliarello, M. (2007). Bank riskiness over the business cycle: A panel analysis on Italian Intermediaries. Applied Financial Econometrics and Statistics, Vol. 17, 119-138.

Salas, V. \& Saurina, J., (2002). Credit risk in two institutional regimes: Spanish commercial and savings banks. Journal of Financial Service Research, 22(3), 203-224.

Santos-Paulino, A. \& Thirlwall, A. P. (2004). The impact of trade liberalisation on exports, imports, and the balance of payments of developing countries. The Economic Journal, 114(493), 50-72.

Shingjergji, A. (2013). The impact of macroeconomic variables on the NPL in the Albanian Banking System during 2005-2012. Academic Journal of Interdisciplinary Studies, 2(9), 335-340.
Tarmidi, L. T. (1999). Krisis moneter Indonesia: Sebab, dampak, peran IMF dan saran. Buletin Ekonomi Moneter dan Perbankan, 1(4), 1-25.

Utari, G.A.D., Arimurti, T. \& Kurniati, I. N. (2012). Pertumbuhan kredit optimal. Buletin Ekonomi Moneter dan Perbankan, 15(2), 113-146.

Viswanadham, N. \& B., Nahid. (2015). Determinants of non performing loan in comercial banks: A study of NBC Bank Sodoma Tanzania. International Journal of Finance and Banking Studies, 4(1), 70-94.

\section{Working Paper}

Babaoucek, I. \& Jancar, M. (2005). Effect of macroeconomic shock to the quality of the aggregate loan portofolio. Working Paper Series. No. 1, Czeh National Bank, 1-62.

Beck, R., Jakubik, P., \& Piloiu, A. (2013). Nonperforming loan: what matters in addtion to economic cycle?. European Central Bank Working Paper Series No. 1555, 1-34.

Bofondi, M. \& Ropele, T. (2011). Macroeconomic determinants of bad loans: Evidence from Italian Banks. Bank of Italy Occasional Paper No. 89, 1-42.

Caprio, G. \& Daniela, K. (2002). Episodes of system and borderine financial crisis. The World Bank Research, 1-21.

Cihak, M. (2007). Introduction to applied stress testing. IMF Working Paper, WP/07/59, 1-76.

Espinoza, R. \& Prasad, A. (2010). Non performing loans in the GCC Banking System and their macroeconomic effect. IMF Working Paper, WP/10/224, 1-25.

Fofack, H. (2005). Non perfoming loan in Sub-Saharan Africa, causal analysis and macroeconomic implication. Word Bank Policy Research Working Paper No. 3769., 1-36

Hoggarth, G., Sorensen, S., \& Zicchino, L. (2005). Stress tests of UK banks using a VAR approach. Bank of England Working Paper No. 292, 1-44.

Keeton, W. R. \& Morris, C. S. (1987). Why do bank loan losses differ?. Federal Reserve Bank of Kansas City. Economic Review, 72(5), 3-21.

Louzis, D. P., Vouldis, A. T., \& Metaxas, V. L. (2010). Macroeconomics and bank-spesific determinants of non performing loan in Greece: A comparative study of mortage, business and consumer loan portofolios. Working Paper Bank of Greece, No. 118, 1-44. 
Morris, G. \& Turner, P. (1996). Banking crises in emerging economies: Origin and policy option. BIS Economic Paper No. 46, 1-67.

Nkusu, M. (2011). Non performing loan and macrofinancial vulnerabilities in Advance Economies. IMF Working Paper WP/11/161, 1-27.

Rinaldi, L. \& Arellano, A. S. (2006). Household debt sustainability: What explain household non performing loans? An empirical analysis. $E C B$ Working Paper No. 570, 1-45.

\section{Tesis dan Disertasi}

Alam, P. P. (2008). Analisis faktor-faktor yang menyebabkan peningkatan non performing loan (NPL) dan dampaknya terhadap penyaluran kredit di sektor UMKM (Studi kasus di Bank BRI). Tesis, Program Studi Manajemen dan Bisnis, Institut Pertanian Bogor.

Bonilla, C. A. O. (2012). Macroeconomic determinants of the non performing loans in Spain and Italy. Unpublished doctoral dissertation, Departement of Economics, University of Leicester.

\section{Sumber Digital}

Bank Indonesia. (2015a). Laporan perekonomian Indonesia. Diperoleh tanggal 20 Desember 2015, dari http://www.bi.go.id/id/publikasi/laporantahunan/perekonomian/Pages/LPI_2014.aspx.

Bank Indonesia. (2015b). Survey perbankan. Diperoleh tanggal 21 Desember 2015, dari http://www.bi.go.id/id/publikasi/survei/ perbankan/Documents/Laporan\%20Survei\%20 Perbankan\%20Triwulan\%20IV\%202014.pdf.

Sarah, V. Rodoni, A. \& Warnida, T. D. (2011). Analisis pengaruh variabel internal dan ekternal terhadap kinerja Bank Go Public di Indonesia. E-Journal. Jurnal Akuntabilitas. Diperoleh tanggal 2 Desember 2015, dari http://journal. aktfebuinjkt.ac.id/?page_id=191. 